University of Illinois-Urbana; Sheridan Johns, Duke University; Paul J. Kaiser, $\mathrm{Ph}$.D. candidate, Indiana University; Daniel R. Kempton, Northern Illinois University; Vincent B. Khapoya, Oakland University; Michael MacDonald, Williams College; Joseph Mathapo, Missouri Valley College; Robert J. Mundt, University of North Carolina-Charlotte; The Rev. Columba Noron, Washington, DC; Thomas Romer, Princeton University; Ian Shapiro, Yale University; Eric Singer, Goucher College; Timothy D. Sisk, U.S. Institute of Peace; Calvin A. Woodward, Valdosta State College; and James J. Zaffiro, Central College.

\section{Ohio State Hosts Faculty Workshop}

The Political Science Department at Ohio State University organized a workshop on Data Analysis for College Faculty. The project was supported by a grant from the National Science Foundation. The APSA has been working with Ohio State University to distribute information about the program. Aage R. Clausen directed the workshop with presentations and research advice offered by

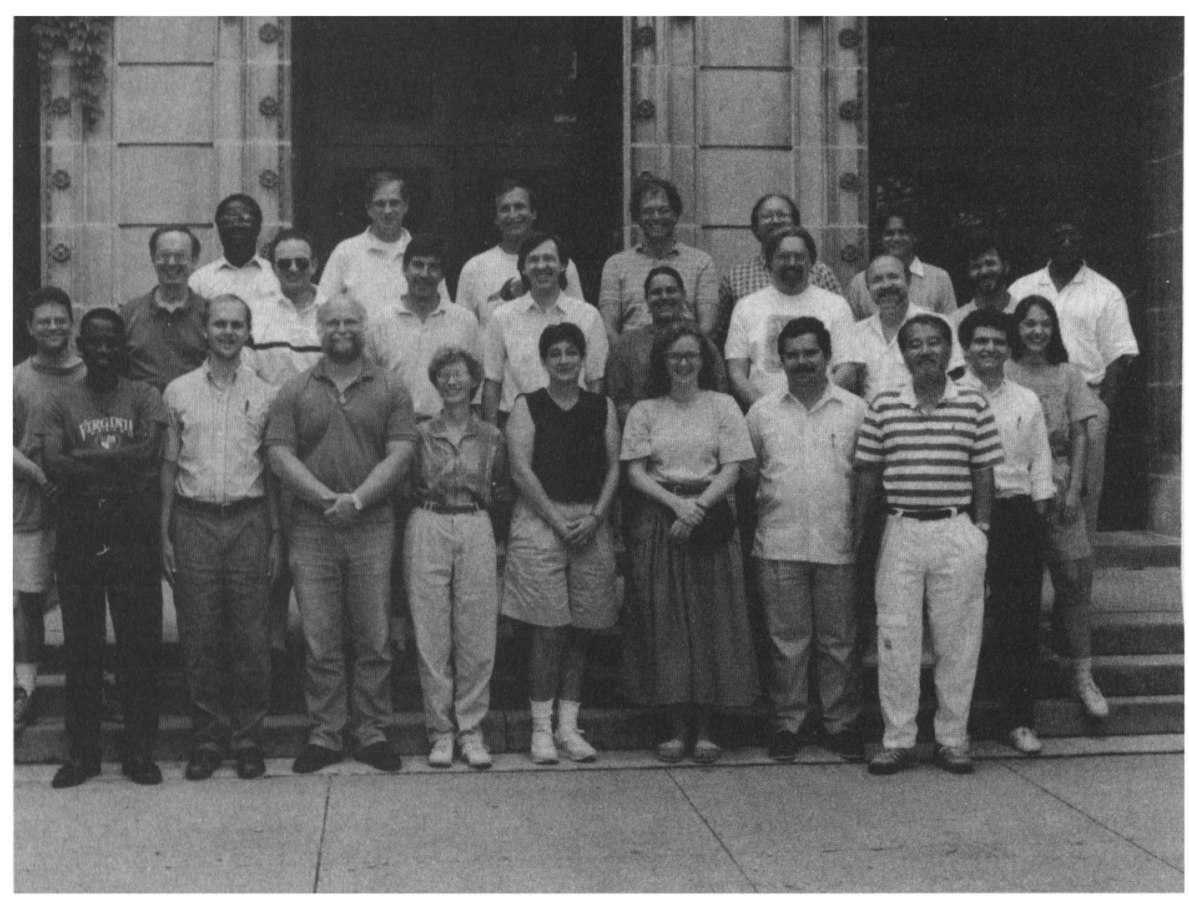

Political science participants at the workshop on Data Analysis for College Faculty at Ohio State University.
Ohio State faculty members including: Herbert B. Asher, Lawrence Baum, Paul Allen Beck, Gregory A. Caldeira, Pradeep Chhibber, Margaret Hermann, Anthony Mughan, Samuel C. Patterson, Brian M. Pollins, Elliott E. Slotnick, Donald A. Sylvan, and Herbert F. Weisberg. Karen Huxtable-Jester, graduate research associate at Ohio State University, served as the workshop coordinator.

The workshop sessions were devoted to facilitating faculty There were hands-on lessons about micro-computers for teaching data analysis, survey research as an instructional tool; review and use of large data sets for teaching many fields of political science, including Comparative Politics, Mass Behavior, International Relations, Judicial Politics, Legislative Voting Behavior, Presidential Elections and Subpresidential Elections, and personal assistance on the participants' own research projects and teaching needs. Participants presented research projects and exchanged suggestions and plans for undergraduate courses in methodology and data analysis. A story about the workshops' curriculum and the participants' experiences, accompanied by a bibliograresearch and undergraduate teaching. phy for use by other faculty who teach data analysis will appear in a 1993 issue of PS: Political Science \& Politics.

Twenty-eight political science faculty attended the workshop. The participants, pictured in the accompanying photograph, included: Mike Avey, Northern Kentucky University; Harry Basehart, Salisbury State University; Roland Blasini, Sheridan College; David Bowers, University of Southern Mississippi; Thomas Brogan, Albright College; Rodney Christy, Saint Michael's College; Roy Dawes, University of Southwestern Louisiana; Pamela Edwards, Wittenberg University; Sally M. Edwards, University of Louisville; Catharine V. Ewing, Phillips University; Keith Fernsler, Dickinson State University; James S. Guseh, SUNY College at Fredonia; Richard Jacobs, St. Mary's College; Tom Kazee, Davidson College; Jeffrey W. Koch, SUNYGeneseo; John F. Kramer, Sonoma State University; Tracy Lightcap, LaGrange College; Theresa Marchant-Shapiro, Union College; Andrew S. Merrifield, Sonoma State University; Robert C. Oberst, Nebraska Wesleyan University; Olusola Olabode, Tougaloo College; Leona Pallansch, Allegheny College; Daniel J. Palazzolo, University of Richmond; Jong O. Ra, Hollins College; Doug Reed, Ouachita Baptist University; James Roberts, Towson State University; Joe Uveges, Western Kentucky University; and Mohamed Yamba, University of Pennsylvania.

\section{Suggestions for Nominating Committee Welcomed}

APSA's Nominating Committee, chaired by Michael Preston, University of Southern California, seeks nominations for APSA offices.

The Committee will make nominations for eight Council persons, as .t well as the offices of treasurer, sectretary, vice-president (three positivons) and president-elect. The Com jmittee will meet in February and re,port to the president no later than ${ }_{x}$ April 15.

Other members of the Nominating Committee are: Gary Orfield, Har- 
vard University; Catherine Kelleher, The Brookings Institution; Joseph Cooper, Johns Hopkins University; Robert Bates, Duke University; and Ellen Frankel Paul, Bowling Green State University. (See form on page 758.)

\section{APSA Announces 1992-93 Congressional Fellows}

The following winners of the 1992-93 Congressional Fellowship Program competition began their orientation in November and will spend nine months working in congressional offices.

\section{Political Science Fellows}

Denise L. Baer, Associate Professor, Department of Political Science, University of Akron

Craig A. Rimmerman, Associate Professor and Chair, Department of Political Science, Hobart and William Smith Colleges (1992-93 William A. Steiger Congressional Fellow)

David J. Webber, Associate Professor of Political Science, University of MissouriColumbia

\section{Journalism Fellows}

Mark C. Curtis, Senior News Reporter, WEAR-TV, Pensacola, Florida (1992-93 Joan Shorenstein Barone Congressional Fellow)

Maureen Groppe, Staff Writer, South Bend Tribune, Indiana (1992-93 Poynter Fellow)

Howard A. Isenstein, General Assignment Business Reporter, The New Haven Register, Connecticut

Peter L. Rosegg, Editorial Writer, The Honolulu Advertiser, Hawaii

\section{APSA-MCI Communications Congressional Fellow}

Shannon LeHere, former Deputy Bureau Chief, Westinghouse Broadcasting, Washington, DC

\section{Robert Wood Johnson Health Policy Fellows}

David F. Altman, M.D., Associate Dean, University of California, San Francisco School of Medicine

William B. Clark, D.D.S., D.M.S., Professor of Oral Biology and Director of the Periodontal Disease Research Center,
College of Dentistry, University of Florida, Gainesville

J. Kevin Eckert, Ph.D., Associate Vice President for Graduate Studies, The University of Maryland Graduate School, Baltimore

Arnold M. Epstein, M.D., M.A., Associate Professor of Health Care Policy, Harvard Medical School

Keith R. Powell, M.D., George Washington Goler Professor and Associate Chair for Clinical Affairs, Department of Pediatrics, and Chief, Division of Infectious Diseases, University of Rochester Medical Center

Julie Sochalski, Ph.D., Assistant Professor, Columbia University School of Nursing, New York

\section{German Fellows}

Bernd Fussy, Ph.D. Candidate, University of Gottingen

Sabine Gans, Student Assistant to Dr. Heinz Laufer, Ludwig-MaximiliansUniversity, Munich

\section{Asia Foundation Fellows}

Fardah Assegaf, Head of Transnational Desk, National News Agency of Indonesia, Antara

Manohar Prasad Bhattarai, Assistant Secretary, Parliament Secretariat, His Majesty's Government of Nepal, Katmandu

Chakorn Pichaiwongse, Associate, Kanung \& Partners Law Office, Bangkok, Thailand

\section{Carl Albert Fellows}

John David Rausch, Jr., Ph.D. Candidate, University of Oklahoma

Mark K. Scribner, Ph.D. Candidate, University of Oklahoma

\section{American Anthropological} Association Fellow

Gregory V. Button, Ph.D. Candidate in Applied Anthropology, Brandeis University

\section{Federal Fellows}

James C. Borland, Senior Computer Specialist, Office of Public Affairs, Department of Agriculture

Matthew J. Bronick, Executive Assistant to the Medical Director, Federal Bureau of Prisons, Department of Justice

Charles A. Casto, Section Chief in Operator Licensing, Operations Branch, Division of Reactor Safety, Nuclear Regulatory Commission
Carolyn G. Conlan, Senior Policy Staff Officer, Plans and Policy Directorate, National Security Agency

Herbert Ford, Career Management Officer, Office of Personnel, Central Intelligence Agency

Clarkson J. Human, Director, Office of Rural Health Policy, Health Resources and Services Administration, Public Health Service, Department of Health and Human Services

Kathleen M. James, Examination Specialist, Office of Policy, Planning and Program Development, Division of Supervision, Federal Deposit Insurance Corporation

Gerald A. Kifer, Management Analyst, Loan Guaranty Service, Department of Veterans Affairs

Melanie A. Miller, Senior Reactor Operations Engineer, Diagnostic Evaluation and Incident Investigation Branch, Division of Operational Assessment, Office of Analysis and Evaluation of Operational Data, Nuclear Regulatory Commission

Raymond J. Miller, LTC, Executive Officer, U.S. Total Army Personnel Command, Department of the Army

Joan Shaw, Correspondence and Issues Management Officer, Reclamation and Enforcement, Office of Surface Mining, Department of the Interior

Stephen E. Thompson, Policy Staff Officer, National Security Agency

Constance A. Wynn, Trial Attorney, Civil Division, Appellate Staff, Department of Justice

Mark E. Wynn, Chief, Hospital Reimbursement, Office of Research and Demonstrations, Health Care Financing Administration, Department of Health and Human Services

\section{Foreign Affairs Fellows}

James W. Bean, Special Assistant to the Assistant Secretary of State for European and Canadian Affairs, Department of State

Michael J. Boyle, External Affairs Officer, Yaounde (United States Information Agency)

Arnold Chacon, Political Officer, American Embassy, Santiago, Chile (Department of State)

Stephen R. Fox, Copyright Officer, Office of Intellectual Property and Competition, Bureau of Economic and Business Affairs, Department of State

Archibald Galloway II, LTC, Staff Officer, Office of the Deputy Chief of 